\title{
Impacts of Forest and Agricultural Land Use on Soil and Litter Arthropod Assemblages in Southern Province of Rwanda
}

\author{
NsengimanaVenuste $\mathrm{e}^{1,2, *}$ \\ ${ }^{I}$ Department of Mathematics, Science and Physical Education, College of Education, \\ University of Rwanda, Rwanda \\ ${ }^{2}$ Center of Excellence in Biodiversity and Natural Resources Management, College of \\ Science and Technology, University of Rwanda, Rwanda \\ *Email: venusteok@gmail.com; ORCID ID: https://orcid.org/0000-0001-5963-8314
}

\begin{abstract}
To assesseffects of land use change on soil and litter arthropods, a research was conducted in exotic and native tree species at the Artboretum of Ruhande and in varieties of coffee and banana plantations at the Rubona agricultural research station, in southern Rwanda. Data were collected by pitfall traps, hand sorting, and Berlese-Tullgren funnels. Collected specimens of soil and litter arthropods were morphologically identified under microscope, and classified to the family level by using dichotomous keys. Fourteen orders and 20 families comprising 2135 individuals were identified. The family of Formicidae was more abundant compared to the other identified families, and occurred in all land uses. High abundance and diversity of soil and litter arthropods werefound under plots of native tree species and banana plantations compared to exotic tree species and coffee plantations. Research concluded that native tree species offer suitable habitats for soil and litter arthropods.It recommendedfurther studies in other land uses and ecological zones of Rwanda to generalize the findings.
\end{abstract}

Key words: arthropod, fauna, land use change, soil and litter

\section{Introduction}

When a natural landshifts from its natural state to a new land use, different changes occur in soil ecosystem and soil fauna (Siqueira et al. 2014). These changes may lead to the loss of the ability of soil to functionproperly, and hence the loss of the capacity of the soil to maintain the growth of plants, and agricultural productivity (Laishram et al. 2012). Land use change may also affect soil fauna. This is measured by comparing the presence of specific individual species or a specificcommunity of soil fauna, before and after land use change interventions (Bartz et al. 2014). Shifts in soil fauna due to the land use change may also be verified by measuring changes in soil processes performed by soil fauna (Wardle et al. 2006). Examples of these processes include changes in nutrient cycling, and the decomposition of soil organic 
matter (Majeed et al. 2019). They may also include changes in soil physical attributes comprising soil aggregation, porosity and water holding capacity (Huerta and Wal 2012).

Soil and litter arthropods constitute a major proportion of soil fauna (Majeed et al. 2019). In relation with land use change, soil and litter arthropods are good biochemical indicators of the environmental change (Rocha et al. 2010; Vasconcellos et al. 2013; Lavelle et al. 2006). In this perspective, measured parametersinclude the diversity, abundance (Barret et al. 2008), and soil ecosystem services provided by soil and litter arthropods (Al-Kaisi and Lowery 2017). Most of land use change that affects soil and litter arthropods include agricultural activities (Siqueira et al. 2014). In this regard, main practices that affect soil and litter arthropods consist of soil physical degradation,soil contamination by pollutants, chemical fertilizers and pesticides, frequent and deep tillage. Further, they include changes in soil cover and poor management of organic residues (Lavelle et al. 2001). Besides agriculture, anotherland use change that is likely to affect soil and litter arthropods includeexotic tree species, whichconsume higher water content and soil nutrients (Zahn et al. 2009).

In Rwanda, land use change is mainly driven by increasing demographic pressure. The majority of the population depends on agriculture and a big part of natural lands was transformed into agricultural lands, dominated by coffee and banana plantations (RDB 2015).To increase the production of coffee and banana, the government of Rwanda encouraged the use of chemical and organic fertilizers, and practice the mono-cropping system (Krista et al. 2016). Coffee plantation relies on small holders (UCDA 2011).It is supported by the government of Rwanda, as an important export product that generate the revenue to the country (GoR 2011). The majority of small holders that grow coffee, also grow bananas, an important food and cash crop production in Rwanda (Jassogne et al. 2013). In addition to crop plantations, another part of the country (13\% of the land cover) isused for forest plantations, planted for sustainable environmental conservation(GoR 2014).

However, nothing is known about the effects of land use change on soil and litter arthropods in Rwanda. This is the reason why, there is an urgent need to document the abundance and diversity of soil and litter arthropods in forest plantations and agricultural lands. This research provided prior information. Its major objective was to identify and compare the diversity and abundance of soil and litter arthropods in four land uses comprising exotic and native tree species and the varieties of coffee and banana. We hypothesized that plots of native tree species offer better conditions for the diversity and abundance of soil and litter arthropods.

\section{Materials and Methods}

\subsection{Study sites}

The Arboretum of Ruhande and the Rubona agricultural research stationwere selected for this study (Figure 1). These areas were preferred due to their historical background in land use change. Theywere used as a human settlement and multiple crop lands until 1930s. In addition, the two areas are located in the same region, and they are separated by a distance of 
$15 \mathrm{~km}$. Geographically, the Arboretum of Ruhande is located at $2^{\circ} 36^{\prime} \mathrm{S}$ and $29^{\circ} 44^{\prime} \mathrm{E}$, at an elevation of 1737- meter (Nsabimana et al. 2009), while Rubona agricultural research station is located at $2^{\circ} 29^{\prime} \mathrm{S}$ and $29^{\circ} 46^{\prime} \mathrm{E}$, at 1750 - meter elevation (Nsengimana et al. 2018).

Currently, the Arboretum of Ruhanda covers an area of around 200 hectares, divided into 504 plots of 50x50m each. Some of these plots are occupied by either native or exotic tree species totalling 207 different tree species (Nsabimana et al. 2008). The Rubona agricultural research station is the first centre for agricultural research in Rwanda. It covers around 675 hectares, and it is mainly used for agricultural research (ISAR1989). The average annual temperature of the region is $20^{\circ} \mathrm{C}$, and the average annual precipitation is $1232 \mathrm{~mm}$ (GoR 2018). Two long dry (June - September) and rainy (March - May) seasons alternate with two short dry (January - February) and rainy (October - December) seasons (Nsabimana et al. 2008).

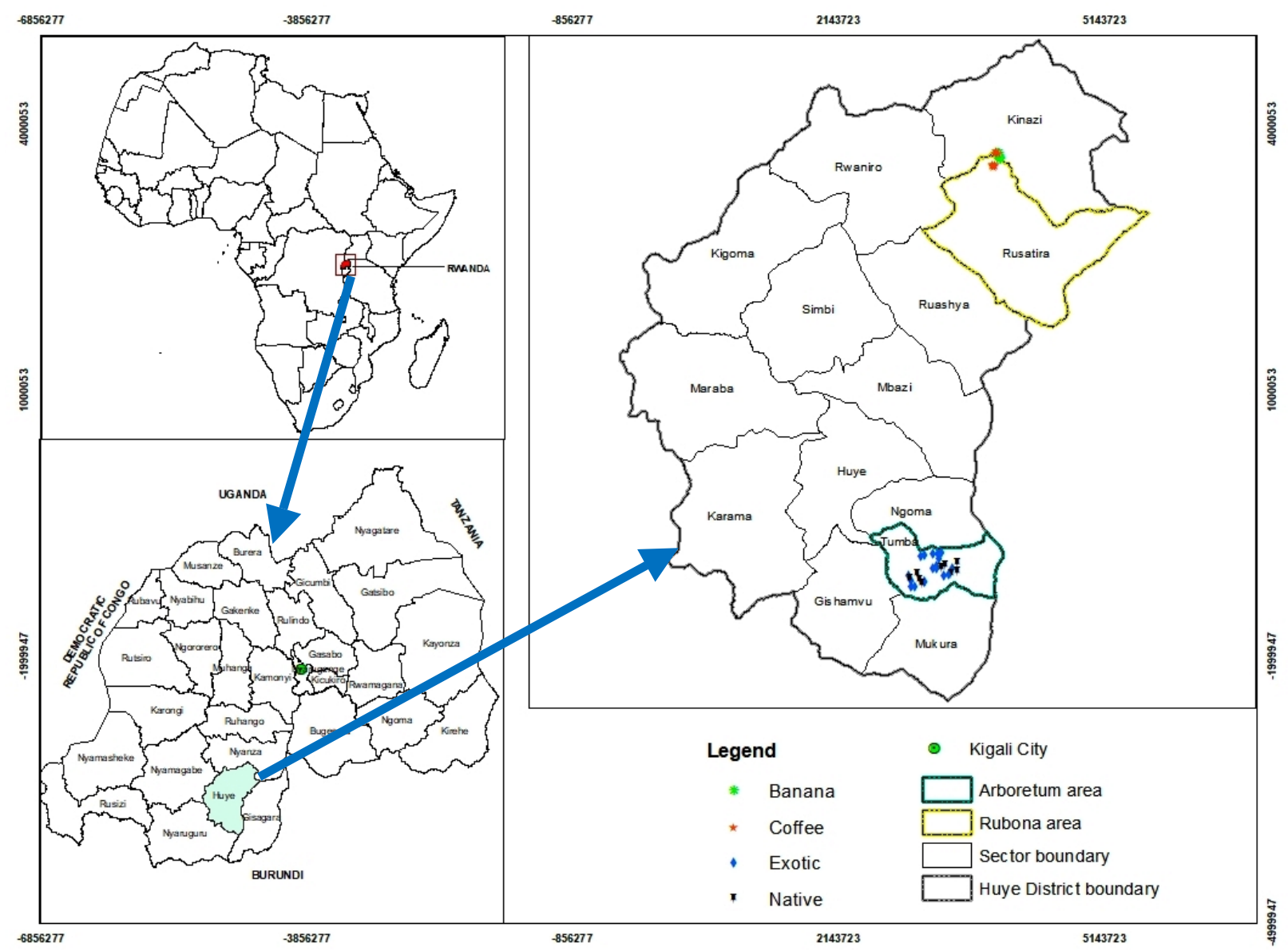

Figure 1:Area of study (Map adapted from the data of the Centre for Geographic Information System, College of Science and Technology, University of Rwanda)

\subsection{Experimental design and sampling techniques}

Soil and litter arthropods were sampled in monodominant stands of exotic and native tree species, and in varieties of coffee and banana plantations. In the Arboretum of Ruhande, three 
different exotic tree species including Eucalyptus maideni, Cedrellaserrataand Grevillea robustawere sampled, while three native monodominant stands comprising Entandrophragmaexcelsum, Polysciasfulva, and Podocarpusfalcatuswere sampled. At Rubona station, samples were collected in HARRAR, JACKSON, and RABC15coffee plantations. Data were also collected in FHIA17, INJAGI, and MPOROGOMAbanana plantations. Sample locations within each plantation type were selected randomly and three replicateseach of $50 \times 50 \mathrm{~m}$ per land use type were sampled. Every replicate was separated from another by a distance of $10 \mathrm{~m}$. Nine sampling points each of $1 \mathrm{~m}^{2}$ in size were placed in each replicate, by living $5 \mathrm{~m}$ from the edge to avoid edge effects. To avoid autocorrelation, each sampling point was separated from the other by a distance of $16 \mathrm{~m}$ (Clark et al. 1996).

\subsection{Arthropod collection and identification}

Data were collected between April (rain period) and July (dry period) 2017. The first step consisted of data collection using the pitfall traps. During this stage, nine pitfall traps were placed in each sampling point for collecting soil and litter arthropods (Vasconcellos et al. 2013).The second stage was the use of hand sorting using a one-meter square pickup point sampling method (McGavin 2007) in $10 \mathrm{~cm}$ soil depth (Sayad et al. 2012). The last stage consisted of the collection of soil cores and leaf litter, and take them to the laboratory for the extraction of soil and litter arthropods using Berlese-Tullgren funnels (Moço et al. 2010).

After the sampling of soil and litter arthropods, the content of pitfall traps, hand sorting and Berlese-Tullgren funnels were separately emptied into individual plastic bottles filled with $20 \mathrm{ml}$ of $75 \%$ ethanol. Samples were taken to the laboratory of Biology, College of Education, University of Rwanda, and analysed separately from others based on the plot number and the land use (Wang et al. 2014). The next step consisted of morphological identification under a microscope. Thefinal step was the classification to the family level using the dichotomous keys in the literature (McGavin 2002; Delvare and Aberlenc 1989; Mignon et al. 2016).

\subsection{Data analysis}

Data were analysed from the plot means within three replicates for each treatment. Total abundance in terms of total number of the mean individual soil and litter arthropods was standardized to dry biomass, which was calculated following length-dry biomass regressions (Schoener 1980). All data were tested for normality and normally distributed data were analysed usingtheANOVAto assess the significance of the differences between the mean values of the abundance in each land use. Non-metric Multidimensional Scaling (NMDS) and the analysis of similarity (ANOSIM) based on Bray-Curtis similarity were used to analyse land use effects on the composition of soil and litter arthropods (Ashford et al. 2013). Further, Shannon biodiversity index $\left(\mathrm{H}^{\prime}\right)$, and the evenness $\left(\mathrm{E}^{\prime}\right)$ were calculated to provide more information on the diversity of soil and litter arthropods (Ashford et al., 2013). All statistical analyses were performed using PAST software (terBraak 1998).

\section{Results}


Data analysis indicated that $46 \%$ of identified soil and litter arthropods were sampled using the pitfall, 34\%dominated by macro-arthropods were sampled using hand sorting. The other $20 \%$ were collected using Berlese funnels. A total of 2135 individuals of soil and litter arthropods comprising fourteen orders and twenty families were identified in this study (Table 1). High abundance of soil and litter arthropods was found under native tree species (35.7\%) and banana plantations (27.1\%). Less abundance was found in soil and litter located under plots of coffee plantations (19.9\%) and exotic tree species (17.3\%). Forest plantations are inhabited by a high number of soil and litter arthropods (53.0\%) compared to agricultural land use $(47.0 \%)$. In addition, significant differences $(\mathrm{P}<0.05)$ were found between soil and litter arthropods sampled in lands used for agriculture and lands used for forest plantations.

The order Hymenoptera, family of Formicidae had highabundance (33.3\%) compared to other identified families, and occurred in all land use. Its proportion by land use varies from $15.9 \%$ in agricultural lands $(7.9 \%$ in banana and $8.0 \%$ in coffee plantations) to $17.6 \%$ in forest plantations (10.4\% in native and $7.2 \%$ in exotic). High abundance in soil and litter arthropods was also found for the families of Julidae (10.4\%), Termitidae (7.2\%),Entomobryidae (5.7\%), and Gryllidae (5.5\%) compared to other identified families (Table 1).

The NMDS (stress $=0.091, \mathrm{X}_{1}=0.73, \mathrm{X}_{2}=0.11$, Figure 2) indicated similarities in soil and litter arthropods across all land uses.However, the axis scoring (Figure 2)showedpositive scores in soil and litter arthropods sampled in native tree species (axis $1=0.4$, axis $2=0.2$ ) compared to exotic tree species (axis $1=-0.4$, axis $2=0.1$ ), coffee (axis $1=-0.4$, axis $2=$ 0.1 ), and banana (axis $1=0.0$, axis $2=-0.4$ ). The normal probability analysis between sample values and normal order statistic medians (Figure 3) indicated relationships between soil and litter arthropods collected in native tree species(correlation coefficient: 0.87 ) and banana plantations (correlation coefficient: 0.80); and between coffee plantations (correlation coefficient: 0.69) and exotic tree species (correlation coefficient: 0.67).Relationships were confirmed by the Bray-Curtis ANOSIM. High similarities were found amongsoil and litter arthropods sampled in plots of exotic tree species and coffee $(\mathrm{R}=44 \%$; Figure 2$)$, compared to soil and litter arthropods sampled inplots of banana and native trees $(\mathrm{R}=31 \%$, Figure 2$)$.

The mean dry biomass per plot differed significantly between plots of exotic and native tree species $\left(\chi^{2}=5.3, \mathrm{P}<0.5\right)$, and between plots of coffee and banana $\left(\chi^{2}=3.3, \mathrm{P}<0.5\right)$. However, there was no significant differences between plots of banana and native tree species $\left(\chi^{2}=1.2, \mathrm{P}>0.5\right)$.Higher diversity of soil and litter arthropods was found in plots of native tree species $\left(\mathrm{H}^{\prime}=2.8 \pm 2.2\right)$ and banana $\left(\mathrm{H}^{\prime}=1.9 \pm 0.1\right)$ plantations. They were low in plots of exotic tree species $\left(\mathrm{H}^{\prime}=1.6 \pm 0.3\right)$ and coffee $\left(\mathrm{H}^{\prime}=1.4 \pm 0.7\right)$. In relation to the evenness $\left(\mathrm{E}^{\prime}\right)$, high values were found in plots of coffee $\left(E^{\prime}=2.1 \pm 0.3\right)$ and exotic tree species $\left(E^{\prime}=1.6 \pm\right.$ $0.4)$, than the plots of native tree species $\left(E^{\prime}=1.1 \pm 0.8\right)$ and banana $\left(E^{\prime}=0.8 \pm 0.3\right)$.

A comparison between the Shannon indices with the evenness indicated that the average Shannon indiceswere higher $\left(\mathrm{H}^{\prime}=2.3 \pm 2.2\right)$ and the average evenness was lower $\left(\mathrm{E}^{\prime}=2.1 \pm\right.$ 
0.3 ) in plots of native tree species and banana plantations, compared to the plots of coffee plantations and exotic tree species $\left(\mathrm{H}^{\prime}=2.7 \pm 0.5\right.$ and $\left.\mathrm{E}^{\prime}=2.4 \pm 0.2\right)$. However, these differences in mean diversity indices were not statistically significant $(\mathrm{F}=2.4, \mathrm{P}=0.07)$. 
Table 1: Abundance (mean \pm standard deviation) of identified ground dwelling arthropods in the litter of exotic and native tree species and coffee and banana plantations in southern Rwanda

\begin{tabular}{|c|c|c|c|c|c|c|c|c|c|c|c|}
\hline \multirow[b]{2}{*}{ Order } & \multirow[b]{2}{*}{ Family } & \multicolumn{2}{|c|}{ Banana } & \multicolumn{2}{|c|}{ Coffee } & \multicolumn{2}{|c|}{ Native } & \multicolumn{2}{|c|}{ Exotic } & \multirow[b]{2}{*}{ Total } & \multirow[b]{2}{*}{$\%$} \\
\hline & & $\begin{array}{l}\text { Number of } \\
\text { individuals }\end{array}$ & $\%$ & $\begin{array}{l}\text { Number of } \\
\text { individuals }\end{array}$ & $\%$ & $\begin{array}{l}\text { Number of } \\
\text { individuals }\end{array}$ & $\%$ & $\begin{array}{l}\text { Number of } \\
\text { individuals }\end{array}$ & $\%$ & & \\
\hline \multirow[t]{2}{*}{ Acari } & Trombiculidae & 12 & 0.6 & 7 & 0.3 & 67 & 3.1 & 9 & 0.4 & 95 & 4.4 \\
\hline & Trombidiidae & 8 & 0.4 & 6 & 0.3 & 53 & 2.5 & 5 & 0.2 & 72 & 3.4 \\
\hline Chilopoda & Geophilidae & 71 & 3.3 & 11 & 0.5 & 28 & 1.3 & 6 & 0.3 & 116 & 5.4 \\
\hline \multirow[t]{3}{*}{ Coleoptera } & Carabidae & 7 & 0.3 & 0 & - & 5 & 0.2 & 0 & - & 12 & 0.6 \\
\hline & Chrysomelidae & 6 & 0.3 & 2 & 0.1 & 7 & 0.3 & 0 & - & 15 & 0.7 \\
\hline & Staphylinidae & 8 & 0.4 & 12 & 0.6 & 5 & 0.3 & 3 & 0.1 & 28 & 1.3 \\
\hline \multirow[t]{2}{*}{ Collembola } & Entomobryidae & 31 & 1.5 & 8 & 0.4 & 68 & 3.2 & 15 & 0.7 & 122 & 5.7 \\
\hline & Isotomidae & 23 & 1.1 & 5 & 0.2 & 43 & 2.0 & 7 & 0.3 & 78 & 3.7 \\
\hline Diplopoda & Julidae & 58 & 2.7 & 62 & 2.9 & 31 & 1.5 & 70 & 3.3 & 221 & 10.4 \\
\hline \multirow[t]{2}{*}{ Diplura } & Cambodeidae & 5 & 0.2 & 6 & 0.3 & 16 & 0.7 & 7 & 0.3 & 34 & 1.6 \\
\hline & Japigydae & 6 & 0.3 & 16 & 0.7 & 14 & 0.7 & 11 & 0.5 & 47 & 2.2 \\
\hline Hymenoptera & Formicidae & 168 & 7.9 & 171 & 8.0 & 222 & 10.4 & 153 & 7.2 & 714 & 33.4 \\
\hline Isopoda & Porcellionidae & 23 & 1.1 & 12 & 0.6 & 27 & 1.3 & 9 & 0.4 & 71 & 3.3 \\
\hline \multirow[t]{2}{*}{ Isoptera } & Rhinotermitidae & 12 & 0.6 & 0 & - & 23 & 1.1 & 0 & - & 35 & 1.6 \\
\hline & Termitidae & 66 & 3.1 & 30 & 1.4 & 34 & 1.6 & 23 & 1.1 & 153 & 7.2 \\
\hline Othroptera & Gryllidae & 28 & 1.3 & 22 & 1.0 & 51 & 2.4 & 16 & 0.7 & 117 & 5.5 \\
\hline Pauropoda & Pauropodidae & 11 & 0.5 & 0 & - & 8 & 0.4 & 6 & 0.3 & 25 & 1.2 \\
\hline Protura & Eosentomidae & 16 & 0.7 & 23 & 1.1 & 27 & 1.3 & 5 & 0.2 & 71 & 3.3 \\
\hline Scolopendrida & Scolopendridae & 7 & 0.3 & 12 & 0.6 & 16 & 0.7 & 10 & 0.5 & 45 & 2.1 \\
\hline
\end{tabular}




\begin{tabular}{|c|c|c|c|c|c|c|c|c|c|c|} 
Symphyla & Scutigerellidae & 13 & 0.6 & 19 & 0.9 & 18 & 0.8 & 14 & 0.7 & 64 \\
\hline Total & $\mathbf{5 7 9}$ & $\mathbf{2 7 . 1}$ & $\mathbf{4 2 4}$ & $\mathbf{1 9 . 9}$ & $\mathbf{7 6 3}$ & $\mathbf{3 5 . 7}$ & $\mathbf{3 6 9}$ & $\mathbf{1 7 . 3}$ & $\mathbf{2 1 3 5}$ & $\mathbf{1 0 0}$ \\
\hline
\end{tabular}




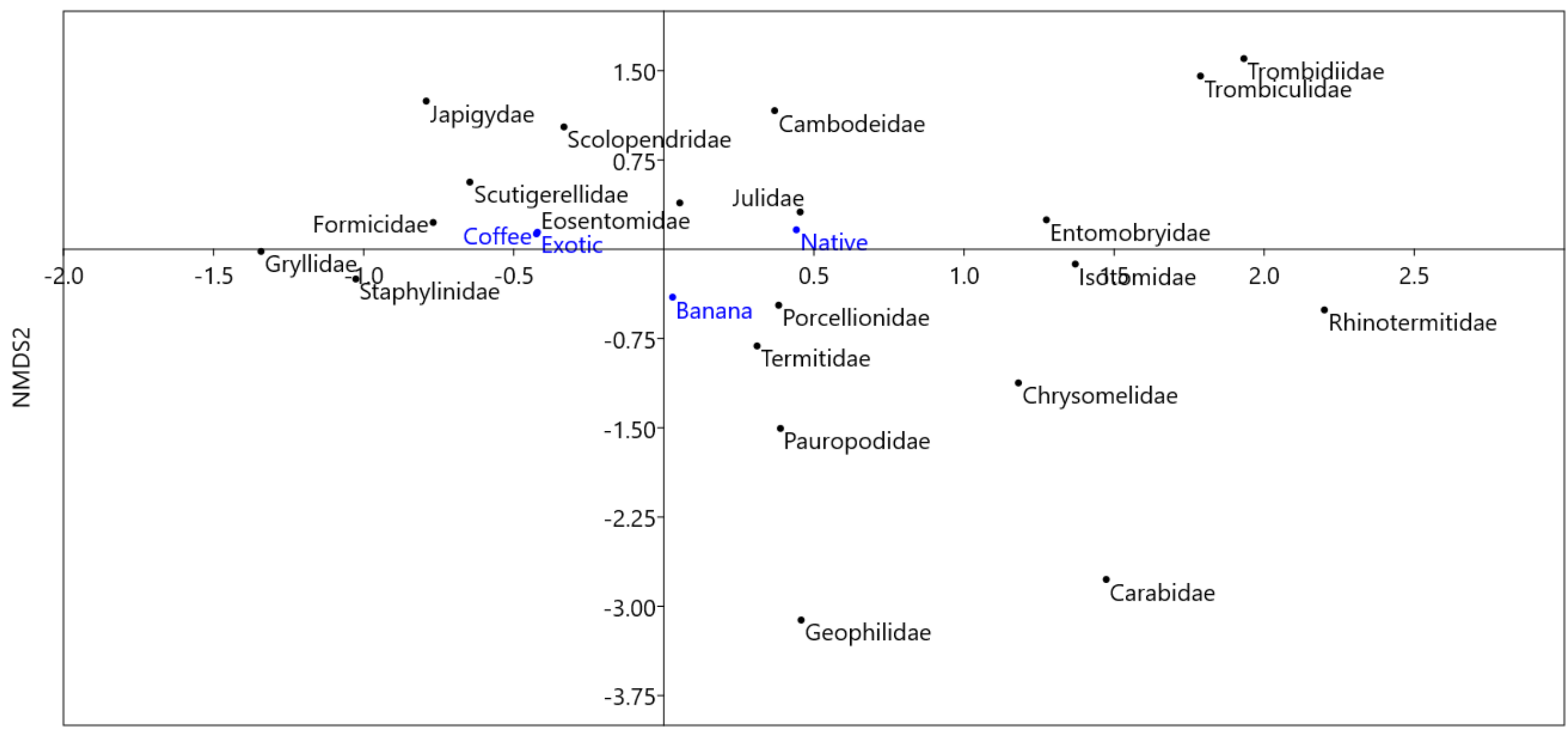

NMDS1

Figure 2: NMDS indicating land use effects on soil and litter arthropods: Bray Curtis similarity index in 2D dimensionality, $1+2$ plot axes(Stress $\left.=0.091, \mathrm{X}_{1}=0.73, \mathrm{X}_{2}=0.11\right)$. 


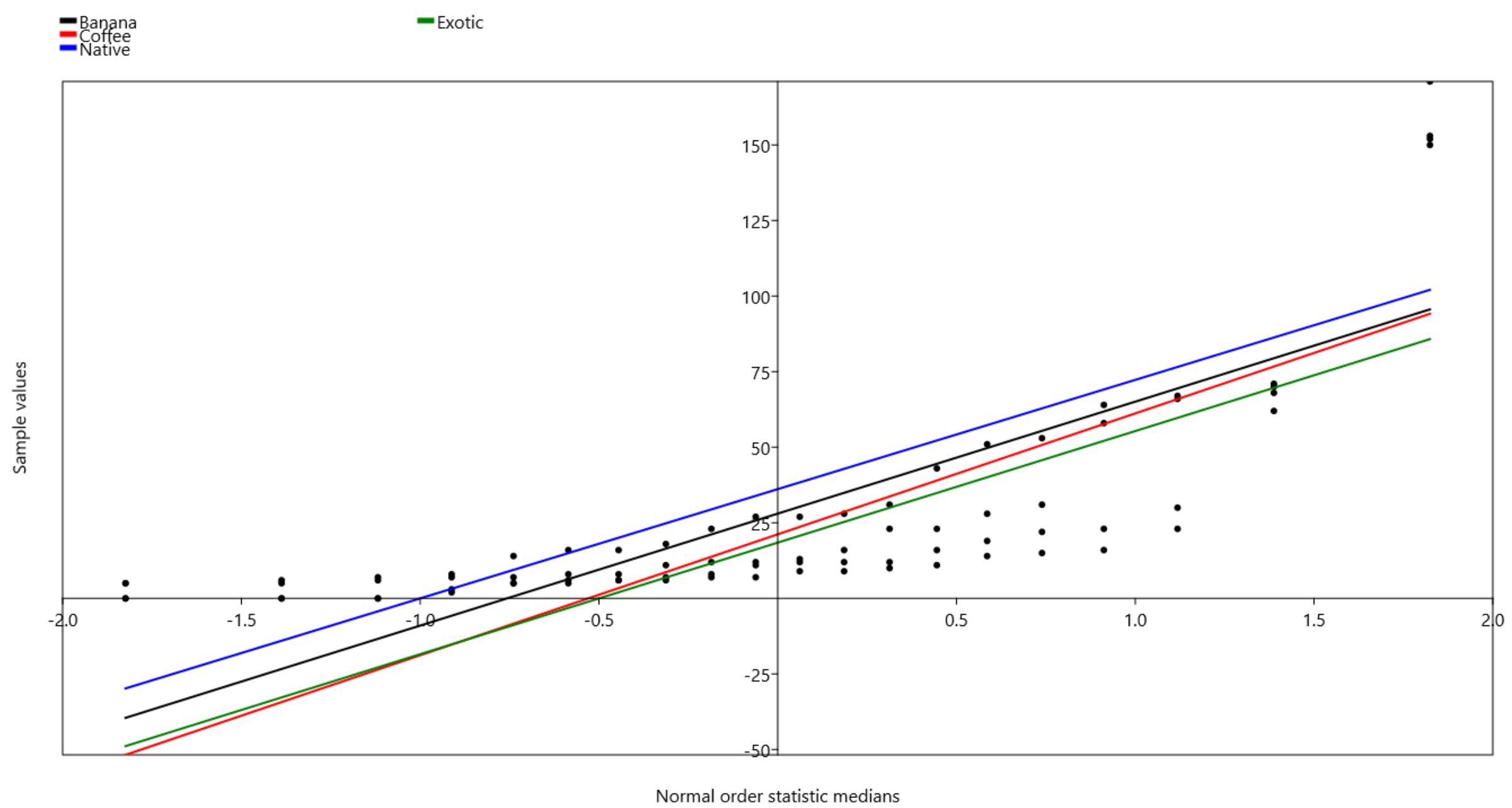

Figure 3: Normal probability plot between sample values and normal order statistic medians in relation with land use 


\section{Discussion}

Plots of exotic, native, coffee and banana have significant influences on soil and litter arthropods. This is supported by the NMDS results, where the stress was 0.091, while the recommended NMDS goodvalueshould be ideally less than 0.1 (Legendre and Legendre 1998).Higher diversity was found in plots of native tree species and banana plantations than in plots of coffee plantations and exotic tree species. These differences in soil and litter arthropod diversity might be associated to the environmental stability, plant diversity, availability of soil nutrients, as well as soil and litter quality. Further, it might be related to water retention in the soil and litter of native forest and banana plantations (Kassa et al. 2017). Poor diversity in soil and litter arthropods in plots of coffee plantations was found to be influenced by the annual tillage which disturbs soils and litter (Beeby 1993). Low diversity in soil and litter arthropods under exotic tree species might be related to the high use of soil nutrients and soil water by monodominant exotic tree species (Zahn et al. 2009)

Higher abundance of Formicidae was documented in other studies. Literature indicated that these insects represent more than $50 \%$ of all eukaryotic species (Grimaldiand Engel 2005). The occurrence and dominance of Formicidae in all land use was found to be associated with their ability to survive in all land use typesand to their mode of life (Ramon andDonoso 2015). They are predators, soil engineers and nutrient cyclers that improve soil physicochemical status (Del Toro et al. 2012). The movement of Formicidae through soil, physically modify, maintain and create suitable habitats for other soil fauna (Ruiz et al., 2008). They facilitate soil aeration, soil porosity and soil texture, and contribute to the availability of soil nutrients and distribution at different soil horizons (Fatima et al. 2008).

In addition to the family of Formicidae, plots of banana plantations were mainly inhabited by the families of Termitidae and Geophilidae. Like Formicidae, Termitidae mediate soil porosity and texture through tunnelling, soil ingestion and transport and gallery construction (Stork andEggleton 1992). They are also nutrient cyclers through transport, shredding and digestion of organic matter and biological controllers as predators (Fatima et al. 2008). In relation to the family of Geophilidae, it is documented that members of this family prefer moist habitats (Bagyaraj et al. 2016). During field data collection, we observed that plots of banana plantations were well weeded and mulched, which might be the cause of suitable soil humidity and hence, suitable habitat for Geophilidae. Other study indicated that members of this family are bioturbators and biopredators that may contribute to soil aeration, increase of mineralization processes, and hence avail nutrients in the soil (Brown et al. 2017).

The family of Entomobryidae and Trombididae had higher abundance in plots of native tree species. Individuals making the family of Entomobryidae are good representatives of the diversity of soil fauna (Cassagne et al. 2003) that interact with ecosystem processes in several ways (Oliveira Filho et al. 2017). Entomobryidae have significant influences on soil microbial ecology, nutrient cycling, and soil fertility by feeding on soil microorganisms and organic matter. They respond to a variety of environmental and ecological factors, like soil 
chemistry, microhabitat configuration and agricultural practices (Hopkin 1997). In addition to the family of Entomobryidae, exotic tree species were also mainly inhabited by the family ofJulidae. Like other diplopoda, individuals making the family of Julidae improve soil ecosystem through the distribution of microbial populations in soil (Szabó et al. 1983). They participate in the decomposition of organic materials contained in the leaf and litter, and hence make nutrients available for bacteria, fungi and plants (Paoletti et al. 2007).

\section{Conclusion}

The analysis of the abundanceindicated a decreasing in soil and litter arthropods from plots of native tree species to the plots of banana and coffee plantations, and exotic tree species. However, plots of native tree species and banana plantations offer better conditions in terms of the diversity of soil and litter arthropods than the plots of coffee plantations and exotic tree species. This research concluded that there is an important role of native tree species in conservation and maintaining high diversity of soil and litter arthropods. However, plots of banana plantations may provide an alternative habitat for soil and litter arthropods than that of coffee plantations and exotic tree species in diversity and abundance respectively.

\section{Acknowledge}

The author thanks the University of Rwanda and Belgium Academy of Research and Higher Education (UR-ARES) and the University of Rwanda - Sweden research (UR-SIDA) program for the financial support during field data collection and laboratory data analysis. He also thanks the Royal Belgium Institute of Natural Sciences (RBINS) for the support inthe identification and confirmation of the names of the families of soil and litter arthropods.

\section{References}

Al-Kaisi, M. and Lowery, B. 2017.Soil Health and Intensification of Agroecosystems, Academic Press, London.

Ashford, O.S., Foster, W.A., Turner, B.L., Sayerm, E.J., Sutcliffe, L., and Tanner, E.V.J. 2013. Litter manipulation and the soil arthropod community in lowland tropical rainforest. Soil Biology and Biochemistry, 62: 5-12.

Bagyaraj, D.J., Nethravathi, C.J., and Nitin, K.S. 2016. Soil Biodiversity and Arthropods: Role in Soil Fertility. In: Chakravarthy, A.K., and Sridhara, S. (Ed.). Economic and Ecological Significance of Arthropods in Diversified Ecosystems. Springer Science and Business Media, Singapore: 17-51.

Barret, J.E., Virginia, R.A., Wall, D.H., and Adams, B.J. 2008. Decline in a dominant invertebratespecies contributes to altered carbon cycling in a low-diversity soil ecosystem. Global Change Biology,14:1734-1744. 
Bartz, M.L.C., Brown, G.G., Orso, R., Mafra, A.L., and Baretta, D. 2014. The influence of land use systems on soil and surface litter fauna in the western region of Santa Catarina. RevistaCiênciaAgronômica,45 (5): 880-887.

Beeby, A. 1993.Applying Ecology.Chapman and Hall, London, UK.

Brown, G.G., Niva, C.C., Zagatto, M.R., Ferreira, A.S., Nadolny, H., Cardoso, G.B.X., Pasini, A., Bartz, M.L., Sauter, K.D., Thomazini, M.J., Baretta, D., Martinez, G.A., Silva, E., Antoniolli, Z.I., Decaens, T., Lavelle, P., Sousa, J.P.F.A., and Varvalho, A. 2017. The role of soil fauna in soil health and delivery of ecosystem services.BurleighDodds Science Publishing Limited. Accessed on 26 November 2019 from http://dx.doi.org/10.19103/AS.2017.03311

Cassagne, N., Gers, C., Gauquelin, T. 2003. Relationships between Collembola soil chemistry and humus types in forest stands (France). Biology and Fertility, 37: 355361.

Clark, D.B., Clark, D.A., Rich, P.M., Wesiss, S., and Oberbauer, S.F. 1996.Landscape-scale evaluation of understory light and canopy structure: methods and application in a Neotropical lowland rain forest. Canadian Journal of Forest Research,26: 747-757.

Del Toro, I., Ribbons, R.R. and Pelini, S.L. 2012. The little things that run the world revisited: a review of ant-mediated ecosystem services and disservices (Hymenoptera: Formicidae). Myrmecological News, 17: 133-146.

Delvare, G., and Aberlenc, H.P. 1989. Les insectesd'Afrique et d'AmériqueTropicale :clé pour la reconnaissance des familles [Insects of Africa and Tropical America : Key for identification of families]. Montpellier, France.

Fatima, M.S.M., Huising, E.J., and Bignell, D.E. 2008.A Handbook of tropical biology: Sampling and characterization of belowground biodiversity. Earth Scan, London, UK.

GoR [Government of Rwanda]. 2018. Comprehensive food security and vulnerability analysis (CFSVA) report. Kigali - Rwanda.

GoR [Government of Rwanda: MINIRENA, IUCN and WRI]. 2014. Forest Landscape Restoration Opportunity Assessment in Rwanda. Kigali - Rwanda.

GoR[Government of Rwanda: MTI. 2011. Rwanda National Export Strategy (NES), March 2011. Ministry of Trade and Industry, Kigali- Rwanda.

Grimaldi, D., and Engel, M.S. 2005. Evolution of the Insects.Cambridge University Press.London, UK.

Hopkin, S.P., Jones, D.Y., and Dietrich, D. 1997. The Isopod Porcellioscaber as a monitor of the bioavailability of metals in terrestrial ecosystems: Towards a global woodlouse watch scheme. Science of the Total Environment, Suppl. 357 - 365. 
Huerta, E.; and Wal, H. 2012. Soil macroinvertebrates abundance and diversity in home gardens in Tabasco, Mexico, vary with soil texture, organic matter and vegetation cover. European Journal of Soil Biology, 50: 68-75.

ISAR [Institut des Sciences Agronomiques du Rwanda (Rwanda Institute of Agricultural Sciences)].1989.A review of agricultural systems research in Rwanda: Report to the director of Rwandan Institute of Agricultural Sciences". International Service for National Agricultural Research. Hague, Netherlands.

Jassogne, L., Nibasumba, A., Wairegi, L., Baret, P.V., Deraeck, J., Mukasa, D. ... and Van Asten, P.J.A. (2013).Coffee/Banana intercropping as an opportunity for smallholder coffee farmers in Uganda, Rwanda and Burundi.In G. Blomme, P. Van Asten and B. Vanlauwe, Banana systems in the humid highlands of sub-Saharan Africa, (p.144149). Wallingford: CABI

Kassa, H., Dondeyne,S.,Poesen,J.,Frank1,A., and Nyssen, J. 2017. Impact of Deforestation on Soil Fertility, Soil Carbon and Nitrogen Stocks: The Case of the Gacheb Catchmentin the White Nile Basin, Ethiopia. Agriculture, Ecosystems and Environment,247:273-282.

Krista, B.I., SnappSieglinde, S., Chung, K., and Waldman, K.B. 2016.Assessing the value of diverse cropping systems under a new agricultural policy environment in Rwanda.Food Security, DOI 10.1007/s12571-016-0582-x.

Laishram, J., Saxena,K. G.,Maikhuri,R. K., and Rao, K. S. 2012. Soil qualityand soil health: a review. Ecology and Environmental Science, 38: 19-37.

Lavelle, P., Barros, E., and Blanchart.E. 2001. SOM management in the tropics: why feeding the soil macrofauna? Nutrient Cycling in Agroecosystems, 61:53-61.

Lavelle, P., Decaëns, T., Aubert, M., Barot, S., Blouin, M., Bureau, F., Margerite, P., Mora, P., and Rossi, J.P. 2006.Soil invertebrates and ecosystem services.European Journal of Soil Biology,42:3-15.

Legendre, P., and Legendre, L. 1998. Numerical Ecology.Developments in Environmental Modelling 20, $2^{\text {nd }}$ Ed. Elsevier Science, Amsterdam, Netherlands.

Majeed, M.Z., Sarwar,I., Afzal,M., Khalid,M.R.,Yahya, M., and Shehzad, K. 2019. Differential composition of edaphic arthropods in different land-use types of district Sargodha (Punjab, Pakistan) and their relationship with soil physico-chemical and biological characteristics. Sarhad Journal of Agriculture, 35(4):1071-1083.

McGavin, G. 2002. Insects, spiders, and other terrestrial arthropods.Smithsonian Handbooks, New York, USA.

McGavin, G.C. 2007.Expedition Field Techniques: insects and other terrestrial arthropods, Blandford Press, UK. 
Mignon, J., Haubruge, E., and Francis, F. 2016. Clé d'identification des principales familles d'insectes d'Europe [Identification Key of principal families of insects of Europe], Les presses Agronomiques de Gembloux, Gembloux, Belgique.

Moço, M.K.S., Gama-Rodrigues, E.F., Gama-Rodrigues, A.C., Machado, R.C.R., and Baligar, V.C. 2010. Relationships between invertebrate communities, litter quality and soil attributes under different cacao agroforestry systems in the south of Bahia, Brazil. Applied Soil Ecology,46:347-354.

Nsabimana, D., Klemedtson, L., Kaplin, B.A., and Wallin, G. 2008. Soil Carbon and nutrient accumulation under forest plantations in Southern Rwanda. African Journal of Environmental Science and Technology, 2:142-149.

Nsabimana, D., Klemedtsson, L., Kaplin, B.A., and Wallin, G. 2009.Soil $\mathrm{CO}_{2}$ flux in six monospecific forest plantations in southern Rwanda.Soil Biology and Biochemistry, 41:396-402.

Nsengimana, V., Kaplin, A. B., Frédéric, F., Kouakou, M.M.L, Dekoninck W., and Nsabimana, D. 2018. Use of soil and litter ants (Hymenoptera: Formicidae) as biological indicators of soil quality under different land uses in southern Rwanda. Environmental entomology,47(6):1394-1401.

Oliveira Filho, L.C.I., KlaubergFilho, O., Baretta, D., Tanaka, C.A.S., and Sousa, J.P. 2016. Collembola Community Structure as a Tool to Assess Land Use Effects on Soil Quality.RevistaBrasileira de Ciência do Solo, doi: 10.1590/18069657rbcs20150432.

Paoletti, M.G, Saupe, S.J., and Clavé, C. 2007. Genesis of Fungal Non-Self Recognition Repertoire.PLoS ONE, 2: 283.

Ramon, G., and Donoso, D. 2015. The role of ants (Hymenoptera: Formicidae) in forensic entomology. REMCB,36:19-26.

RDB [Rwanda Development Board]. 2015. Identification of potential sources of rapid and sustainable growth within the agricultural sector. Kigali - Rwanda.

Rocha, J.R.M., Almeida, J.R., Lins, G.A., and Durval, A. 2010. Insects as indicators of environmental changing and pollution: A review of appropriate species and their monitoring. Holos Environment, 10: 250-262.

Ruiz, N., Lavelle, P., and Jimenez, J. 2008. Soil macrofauna field manual: Technical level. Food and Agricultural Organization of the United Nations. Roma, Italy.

Sayad, E., Hosseini, S.M., Hosseini, V., and Shooshtari, M.H. 2012.Soil Macrofauna in relation to soil and leaf litter properties in tree plantations.Forest Science, 4: 170-180.

Schoener, T.W. 1980. Length-weight regression in tropical and temperate understory insects.Annals of Entomological Society of America,73: 106-109. 
Siqueira, G.M., Silva, E.E.F., and Paz-Ferreiro, J. 2014. Land use intensification effects in soil arthropod community of an Entisol in Pernambuco State, Brazil. The Scientific World Journal, 2014: 1-7

Stork, N.E., and Eggleton, P. 1992. Invertebrates as determinants and indicators of soil quality.American Journal of Alternative Agriculture, 7: 38-47.

Szabó, I.M., Jáger, K., Contreras, E., Márialigeti K., Dzingov, A., Barabás, G., and Pobozsny, M. 1983. Composition and Properties of the External and Internal Microflora of Millipedes (Diplopoda), In: Lebrun P., André H.M., de Medts A., Grégoire-Wibo C., and Wauthy G. (Ed.). New Trends in Soil Biology.Louvain-la-Neuve, Belgium: 197 205.

terBraak, C.J.F. 1998. Canonical Correspondence Analysis: A new eigenvector technique for multivariate direct gradient analysis. Ecology,67: 69-77.

UCDA. 2011. Uganda Coffee Development Authority: Production. Kampala - Uganda. Retrieved on 16/2019 from: http://www.ugandacoffee.org/index.php?pageanda=15.

Vasconcellos, R.L.F., Segat, J.C., Bonfin, A.J., and Baretta, D. 2013. Soil macrofauna as an indicator of soil quality in an undisturbed riparian forest and recovering sites of different ages.European Journal of Soil Biology, 58: 105-112.

Wang, J., Xiaoli, T., and Donghui, W. 2014. The effects of latitudinal gradient on the species diversity of Chinese litter dwelling thrips. Zookeys,417: 9-20.

Wardle, D.A., YEates, G.W., Barker, G.M., and Bonner, K.I. 2006. The influence of plant litter diversity on decomposer abundance and diversity. Soil Biology and Biochemistry,38(5): 1052-1062

Zahn, A., Rhaino, A., Rodrigues, L., and Palmeirin, J.M. 2009.Low macro-arthropod abundance in exotic Eucalyptus plantations in the Mediterranean. LudwigMaximilians - UniversätMünchen, München, Germany: 240 -257. 